\section{ZNAČAJ RAVNOTEŽE ZA IZVOĐENJE TEHNIKE BACANJA IZBIJANJEM NOGE OTPOZADI}

\section{THE IMPORTANCE OF BALANCE FOR THE PERFORMING THE MAJOR OUTER REAP THROW TECHNIQUE}

\section{SAŽETAK}

Cilj istraživanja je da se utvrdi povezanost ravnoteže kao motoričke sposobnosti sa izvođenjem tehnike bacanja izbijanjem noge otpozadi (prema programu Specijalnog fizičkog obrazovanja - SFO) radi eventualne izmjene obučavanja navedene tehnike $i$ odabira adekvatnih sredstava u poboljšanju iste. Istraživanje je provedeno na uzorku od 67 ispitanika muškog pola. Uzorak varijabli činilo je osam standardizovanih testova za procjenu motoričke sposobnosti ravnoteže, te varijabla za procjenu nivoa usvojenosti tehnike bacanja izbijanjem noge otpozadi iz programa SFO-a. Analizom rezultata, dobijenih regresionom analizom, utvrđeno je da ne postoji statistički značajna povezanost varijabli za procjenu ravnoteže sa efikasnošću izvođenja tehnike bacanja izbijanjem noge otpozadi. Budući da se nije pokazla statistički značajna povezanost primijenjenih testova za procjenu ravnoteže sa izvođenjem posmatrane tehnike, obavezuje da se u budućim sličnim istraživanjima konstruišu ili odaberu konzistentni, specifični testovi koji bi preciznije objasnili povezanost ravnoteže sa kvalitetom izvođenja tehnike bacanja izbijanjem stajne noge.

\section{Darko Paspalj ${ }^{1}$ i Milan Gužvica ${ }^{1}$}

${ }^{1}$ Fakultet bezbjednosnih nauka, Univerzitet u Banjoj Luci, Bosna i Hercegovina

Originalni naučni rad

Primljeno: 06.05.2017. Odobreno: 26.06.2017.

Originalni naučni rad doi:10.5550/sgia.171301.se.PG

UDK: 796.433.012.266 COBISS.RS-ID 6759448

Korespodencija:

Doc. dr Darko Paspalj

Fakultet bezbjednosnih nauka Univerzitet u Banjoj Luci Bulevar vojvode Živojina Mišića 10 a, 78000 Banja Luka Bosna i Hercegovina Tel:+38751333603 +38765906325 dpaspalj@yahoo.com

Sportlogia 2017, 13 (1), 18-28. E-ISSN 1986-6119

Ključne riječi: ravnoteža, tehnika izvođenja, povezanost 


\section{UVOD}

Tehniku programskih sadržaja Specijalnog fizičkog obrazovanja predstavlja sistem racionalnih pokreta i kretnji koji se ispoljavaju u dostignutim nivoima usvojenosti, kao što su npr. tipizirana kretanja, blokovi, udarci, bacanja, čišćenja i poluge (Gužvica, 2006), pri čemu, pored ostalih sposobnosti i karakteristika, motoričke sposobnosti imaju veliki značaj. Izvođenje tehnika uzrokuje određene promjene u prostoru i vremenu, pri čemu pojedini segmenti tijela mijenjaju međusobni položaj, pa samim tim remete i ravnotežu. Sekulić i Metikoš (2007) su utvrdili da je ravnoteža sposobnost održavanja tijela u određenom položaju za vrijeme mirovanja, ali i sposobnost brzog uspostavljanja stabilnog položaja cijelog tijela pri različitim pokretima i kretanjima. Nićin (2000) zaključuje da je ravnoteža bazična motorička sposobnost održavanja tijela u izbalansiranom stavu (položaju) koja zavisi od mnoštva faktora, od kojih su najznačajniji: genetska određenost, stanje centra za ravnotežu u mozgu, stanje vestibularnog aparata, uzrast, površina oslonca, visina težišta tijela, brojnost motoričkih navika i treniranost. U mehanici se ravnotežni položaji klasifikuju prema ponašanju tijela pod dejstvom sila koje teže da promijene njihov položaj, dok većinu položaja tijela čovjek održava aktivnim mišićnim silama (Jarić, 1997). Imajući u vidu činjenicu da je ravnoteža sposobnost očuvanja stabilnog položaja tijela kod raznolikih pokreta (kretanja) i položaja, odnosno sposobnost da se tijelo zadrži u zadanom položaju, razlikuju se statička i dinamička ravnoteža. Statička ravnoteža se odnosi na održavanje zadatog položaja u mirovanju, gdje statičkim naprezanjem treba zadržati zadani položaj pri čemu je površina oslonca nepromjenjiva, dok se pod dinamičkom ravnotežom podrazumijeva sposobnost održavanja stabilnog položaja tijela koje je u pokretu (aktivnosti u kojima se često izvode brze promjene položaja tijela u prostoru) kojom prilikom najčešće dolazi do promjene površine oslonca tijela. Kosinac (2009) smatra da dobra ravnoteža zahtijeva dobro integrisani nervni sistem sa adekvatnim aferentnim ulazom, pokretne zglobove i zdrave mišiće, pri čemu poremećaj bilo kojega od ovih faktora smanjuje sposobnost održavanja ravnoteže. Po njemu ključnu ulogu u svim pokretima, tj. kontrakcijama $\alpha$-motoneurona, imaju osjetne informacije, što znači da one imaju i ključnu ulogu u držanju tijela. Aktivnosti $\alpha$-motoneurona izravno mogu mijenjati samo osjetni signali iz perifernih receptora i zapovjedni signali silaznih moždanih puteva. Upravo se ti osjetni signali iz perifernih receptora ubrajaju u mehanizme kontrole držanja tijela, jer se centar za ravnotežu nalazi u malom mozgu, pri čemu je kod održavanja ravnoteže neophodno uključivanje vestibularnogi somatosenzitivnog sistema. Ovo je važno zato što informacije o narušenoj ravnoteži dolaze iz vestibularnog aparata u mali mozak, gdje se pravi program korekcije, na osnovu čega slijedi brz odgovor kroz adekvatne pokrete kojima se nastoji što prije povratiti stabilan ravnotežni položaj tijela, iz čega proizlazi da su vestibularni aparat i mali mozak veoma važan regulator tonusa mišića (ibid). U istraživanjima koja je vršio Golab 1962. (po Zaciorskom) ustanovljeno je da statička i dinamička ravnoteža međusobno veoma malo koreliraju. Takođe je ustanovljeno da, pri održavanju stabilnog ravnotežnog položaja, čovjekovo tijelo nije apsolutno nepokretno, već se ono sve vrijeme „uravnotežava“, i bez obzira na to što se to kretanje ne odlikuje parametrima lokomocije (amplitude pokreta su veoma male i često neprimijetne), ono se ipak vrši u zglobovima koji su blizu površine oslonca. Iz toga i proizlazi potreba da se sposobnost zadržavanja ravnotežnog položaja diferencira s obzirom na način djelovanja sile, način korištenja vidnog analizatora, te veličinu površine na kojoj se ravnoteža održava. Stabilnost tijela u mirovanju zavisi od težine tijela, sile mišića koji održavaju tu stabilnost, te površine oslonca, pri čemu je izvođač tehnike u ravnotežnom položaju tako dugo dok je neka vanjska sila koja djeluje na njega (moment sile napadača) manja od momenta sile teže onoga koji ga napada (Kuleš, 2008). Dinamički

Paspalj, D., et al.: Značaj ravnoteže...Sportlogia 2017, 13 (1), 18-28. Stranica 19. 
pokazatelj stabilnosti ravnotežnog položaja u nekom stavu izražava se uglom sigurnosti koji formiraju projekcija opšteg centra težišta tijela i spoljašnji rub površine oslonca, pri čemu se ugao sigurnosti povećava sa povećanjem površine oslonca i snižavanjem opšteg centra težišta (OCT). To navodi na zaključak da što je ugao veći, tijelo je u boljoj ravnoteži, iz čega proizlazi da izvođač tehnike može sačuvati svoju ravnotežu sve dotle dok projekcija OCT-a ne izađe izvan njegove oslonačke površine (Jarić, 1997). Kod realizacije pokreta i kretanja karakterističnih za program SFO-a veoma je važno naglasiti da oni počinju i završavaju se u stabilnoj ravnoteži, pri čemu se težište tijela nalazi iznad površine oslonca. U okviru aktuelnog studijskog programa Fakulteta bezbjednosnih nauka Univerziteta u Banjoj Luci, u sklopu programa SFO-a, do nivoa utilitarnosti, pored drugih tehnika, uče se i tehnike bacanja iz džuda koje se sa aspekta biomehaničkog načina izvođenja mogu podijeliti na: tehnike bacanja čišćenjem (de ashi barai i okuri ashi barai), tehnike bacanja izbijanjem (o soto gari i harai goshi), tehnike bacanja obuhvatom (ippon seoi nage, koshi guruma, o goshi i morote gari), te tehnike bacanja blokom (sasae tsuri komi ashi i tai otoshi). U SFO-u tehnike bacanja predstavljaju složene kretne strukture namijenjene prvenstveno destabilizaciji na putu do uspostavljanja potpune kontrole nad njim. Tehnike se najčešće izvode u samoodbrani kao tehnike kontranapada (iako imaju primjenu i u direktnom napadu). Efikasnost njihove realizacije zavisi od pravovremenosti započinjanja, vremena trajanja izvođenja i kontrole prije, u toku i nakon njihove primjene. Tehnike se izvode nakon hvata ili obuhvata dijelova tijela protivnika, tako što se vrši prenošenje sopstvenog kretanja na tijelo protivnika (Arlov, 2001). Drid (2005) tvrdi da je u međusobnoj borbi tokom obostranog napada uspješniji onaj koji dobro vlada tehnikom, koji zna da održava vlastitu ravnotežu, a da pritom istovremeno remeti protivnikovu ravnotežu i koristi njegove greške pri izvođenju određenih napada ili zahvata. Već je ranije pomenuto da uspješnost bacanja determinišu snaga, brzina, pravovremenost i preciznost, pri čemu je veoma važno da se pozicija vlastitog tijela prilagodi položaju tijela protivnika, kako bi se uz najmanji utrošak energije izvršilo bacanje. Dakle, izvođenje bacanja se vrši velikom brzinom, pri čemu je moguće izdvojiti sljedeće faze: fazu narušavanja ravnoteže protivnika, fazu uspostavljanja kontakta sa protivnikom i fazu realizacije samog bacanja. Sve ove faze međusobno su povezane i čine jednu cjelinu, pri čemu efikasnost njihove realizacije zavisi od preciznog i brzog (eksplozivnog) izvođenja svih faza (Milošević, 2013). Svaku od ovih faza karakterišu specifična kretanja (trajektorije pojedinih segmenata tijela) sa maksimalnom međusobnom zavisnošću. Narušavanje protivnikove ravnoteže ima za cilj stvaranje pogodnih uslova za izvođenje zamišljene tehnike, pri čemu je najbitnije da se projekcija težišta tijela protivnika udalji što više od površine centra oslonca, što se najčešće izvodi u kretanju korištenjem inercijalne sile i težine protivnika (povlačenjem ili guranjem), a zavisi od reakcije i kretanja protivnika (ibid). Ostvarivanje kontakta sa protivnikom može se izvoditi u svim navedenim pravcima, pri čemu način izvođenja tehnike zahtijeva brzu primjenu kako se protivnik ne bi vratio u ravnotežni položaj. Prema prvome načelu bacanje se izvodi zakretanjem tijela izvođača oko tačke blokiranja (stopala, potkoljenice, koljena, natkoljenice i kukova), a prema drugom, zakretanjem izvođačevog tijela spregom suprotno usmjerenih sila. Ovom prilikom potrebno je naglasiti da ukoliko je krak momenta sile veći, odnosno što je okretište niže, to će i momenat rotacije biti veći, jer napadačevu silu povećava komponenta sile teže. Za efikasnost izvođenja tehnika bacanja izbijanjem stajne noge bitno je da projekcija težišta protivnika pada u tačku oslonca, čime se mogućnost njegovog otpora svodi isključivo na pasivan statički otpor (ibid). Iz navedenog se vidi da efikasnost bacanja u prvom redu zavisi od nestabilnosti protivnikove ravnoteže i korektno izvedenih pripremnih pokreta za bacanje (koji podrazumijevaju stabilan ravnotežni položaj

Paspalj, D., et al.: Značaj ravnoteže...Sportlogia 2017, 13 (1), 18-28. Stranica 20. 
izvođača), što zahtijeva da se pojasni značaj ravnoteže u samoj primjeni tehnike izbijanjem noge otpozadi iz programa SFO. Razlog zbog kojeg ova tehnika ima svoju odgovarajuću primjenu u programu SFO-a je u tome što se početna faza bacanja izvodi guranjem protivnika unazad, pri čemu direktan i brz ulazak u ovo bacanje omogućava da se težina tijela izvođača prenosi na protivnika zbog čega on gubi ravnotežu jer nema vizualnih kontakata sa smjerom u kojem se kreće, pa mu je iz tog razloga teže uspostaviti ponovno poziciju stabilne ravnoteže i organizovati odbranu. Poput gotovo svih drugih tehnika bacanja i tehniku bacanja izbijanjem noge otpozadi karakterišu tri faze: faza narušavanja ravnoteže protivnika, faza uspostavljanja kontakta sa protivnikom i faza realizacije samog bacanja. Sve ove faze međusobno su povezane i čine jednu cjelinu, pri čemu efikasnost njihove realizacije zavisi od preciznog i brzog (eksplozivnog) izvođenja svih faza (ibid). Svaku od ovih faza karakterišu specifična kretanja (trajektorije pojedinih segmenata tijela) sa maksimalnom međusobnom zavisnošću. Bacanje se izvodi iz osnovnog stava i desnog garda u momentu kada protivnik zakorakom desnom nogom unazad povlači izvođača ka sebi narušavajući mu ravnotežu. U momentu narušavanja ravnoteže izvođač refleksnom kretnjom nastoji zadržati stabilnu ravnotežu tako što vrši iskorak lijevom nogom prema naprijed u lijevu stranu za oko 15 do $20 \mathrm{~cm}$ od protivnikovog desnog stopala, čime je u potpunosti prenio težinu na lijevu nogu i stabilizovao ravnotežni položaj. U nastavku aktivnosti izvođač istovremenim povlačenjem lijevom rukom protivnikove desne ruke prema pojasu i guranjem desnom rukom protivnikovog lijevog ramena i lijeve strane tijela ulijevo, protivniku narušava ravnotežu. Dalje, snažnim uvrtanjem tijela u spoljašnju stranu pod uglom od 45 stepeni (neprekidan kontakt sa protivnikom) on protivnika dovodi u neravnotežan položaj, smanjujući mu površinu oslonca (uslovljavajući ga da stoji na spoljnoj strani stopala desne noge). U nastavku akcije rotacijom karlice ulijevo izvođač vrši izmahivanje desnom nogom naprijed (iza protivnikove desne noge, tako da su glava i prsti desne noge u istoj ravni), nakon čega istovremenim savijanjem tijela naprijed i nadolje, snažnim zamahom istom (polusavijenom) nogom unazad uspostavlja kontakt u pregib koljena protivnikove desne noge, izbijajući mu nogu nazad i nagore. Izvođač sinhronizovanim i snažnim vučenjem lijevom rukom ka sebi i guranjem desnom rukom nadolje baca protivnika ispred sebe (usmjerivši ga, pritom tako da pada lijevom stranom tijela na podlogu). Veoma je važno da kod izbijanja protivnikove noge izvođač zadrži stabilnu ravnotežu. To postiže tako što cjelokupnu težinu tijela prebaci na prednji dio stopala stajne noge, koja mu omogućava da u potpunosti kontroliše pad protivnika na podlogu. Iskustvo je pokazalo da je u datim uslovima održavanje stabilnog ravnotežnog položaja veoma kompleksno i značajno za učenje i usvajanje motoričkih programa iz SFO-a, zato i jeste ravnoteža predmet ovog istraživanja. U tom smislu cilj istraživanja jeste da se utvrdi povezanost ravnoteže kao motoričke sposobnosti sa izvođenjem tehnike bacanja izbijanjem noge otpozadi iz programa SFO, radi eventualne izmjene obučavanja navedene tehnike i odabira adekvatnih sredstava u poboljšanju iste. 


\section{METODE}

Ukupna edukacija tehnike bacanja izbijanjem noge otpozadi trajala je ukupno šest nastavnih časova tokom tri sedmice, a realizovala se za vrijeme održavanja redovne nastave sa studentima prve godine Fakulteta bezbjednosnih nauka u toku drugog semestra u kabinetu za borilačke sportove Fakulteta fizičkog vaspitanja i sporta u Banjoj Luci. Efikasnost izvođenja tehnike bacanja izbijanjem noge otpozadi utvrđena je ekspertskom ocjenom od strane pet ispitivača (eksperata za SFO). Tehnike su izvođene po tri puta, pri čemu su ispitanici bili bočno okrenuti u odnosu na ispitivače. Primjena ovakvog načina ocjenjivanja zahtijevala je i određene pripreme ocjenjivača za ocjenjivanje, prilikom kojih je ocjenjivačima, radi usaglašavanja kriterijuma ocjenjivanja, prikazan film sa izvođenjem tehnike izbijanjem stajne noge otpozadi i prikazan dijagram sa određenim fazama na koje treba posebno obratiti pažnju: izvlačenje iz ravnoteže, uspostavljanje kontakta, ulazak sa odgovarajućom pozicijom za bacanje i samo izvođenje bacanja.

Uzorak ispitanika činilo je šezdeset sedam studenata (67) prve godine Fakulteta bezbjednosnih nauka, muškog pola. Ispitanici su predstavljali populaciju fizički aktivnih osoba, starosti $19 \pm 0,6$ godina, klinički zdravih, bez vidljivih tjelesnih nedostataka ili morfoloških aberacija. Osnovni antropomorfološki pokazatelji testiranog uzorka su iznosili: TV $=181,40 \pm$ $5,90 \mathrm{~cm}, \mathrm{TM} 78,60 \pm 10,18 \mathrm{~kg}$ i BMI 23,87 $\pm 2,51$.

Uzorak varijabli u ovom istraživanju podijeljen je na prediktorske varijable i kriterijumsku varijablu. Uzorak prediktorskih varijabli sačinjavao je set od osam (8) provjerenih i u praksi provođenih testova za procjenu sposobnosti održavanja ravnoteže: MBAU20 (stajanje na dvije noge uzdužno na klupici za ravnotežu s otvorenim očima), MBAU10 (stajanje na jednoj nozi uzdužno na klupici za ravnotežu s otvorenim očima), MBAP20 (stajanje na dvije noge poprečno na klupici za ravnotežu s otvorenim očima), MBAP10 (stajanje na jednoj nozi poprečno na klupici za ravnotežu s otvorenim očima), MBAU2Z (stajanje na dvije noge uzdužno na klupici za ravnotežu sa zatvorenim očima), MBAU1Z (stajanje na jednoj nozi uzdužno na klupici za ravnotežu sa zatvorenim očima), MBAP2Z (stajanje na dvije noge poprečno na klupici za ravnotežu sa zatvorenim očima), MBAP1Z (stajanje na jednoj nozi poprečno na klupici za ravnotežu sa zatvorenim očima). Sve varijable za procjenu motoričke sposobnosti - ravnoteže posjeduju potrebne metrijske karakteristike (Metikoš, Hofman, Prot, Pintar i Oreb, 1989).

Kriterijumsku varijablu činila je ocjena izvođenja bacanja izbijanjem noge otpozadi, a formirana je izvođenjem prosječne ocjene od strane pet eksperata koji predaju SFO-e u skali od 5,00 do 10,00. Kriterijum ocjenjivanja je bio sljedeći:

Ocjena 10 (deset) bila je dodijeljena za besprekorno izvedenu tehniku bacanja, u optimalnom ritmu, koja zadovoljava osnovne biomehaničke principe i omogućava bezbjednu i potpunu kontrolu.

Ocjena 9 (devet) bila je dodijeljena za odlično izvođenje tehnike, odnosno za tačno, bez tehničkih grešaka izvedenu tehniku, uz adekvatnu snagu, brzinu i amplitudu izvedenog bacanja.

Ocjena 8 (osam) bila je dodijeljena za bacanje koje, s tehničke strane, nije u potpunosti tačno izvedeno ili nije izvedeno dovoljno snažno, brzo, protivnik nije imao zadovoljavajuću amplitudu leta, odnosno, ako je izvođač napravio neku grešku u tačnom izvođenju tehnike, kao što su nedovoljano izbacivanje protivnika iz ravnoteže ili nepravilan kontakt sa tijelom protivnika.

Ocena 7 (sedam) bila je dodijeljena za bacanje koje je bilo izvedeno s bar dvije greške ili ako je bacanje bilo izvedeno sa nedovoljnom amplitudom, odnosno da nisu bile tačno i

Paspalj, D., et al.: Značaj ravnoteže...Sportlogia 2017, 13 (1), 18-28. Stranica 22. 
kvalitetno izvedene dvije od tri faze bacanja: izvlačenje iz ravnoteže, ostvarivanje kontakta sa protivnikom i završna faza bacanja.

Ocena 6 (šest) bila je dodijeljena za bacanje izvedeno s očiglednom greškom u tehnici izvođenja. Pod tim se podrazumijeva očigledan nedostatak ili pogrešno izvođenje jedne od prvih dviju faza bacanja (izvlačenje iz ravnoteže i ostvarivanje kontakta), te nedostatak ili pogrešno izvođenje nekog segmenta bacanja. To podrazumeva da bacanje nije izvedeno odgovarajućom snagom, brzinom i nema potrebnu amplitudu leta, ali ipak postoje bar dvije faze bacanja, te se kao takvo može prepoznati.

Ocena 5 (pet) bila je dodijeljena za bacanje koje u potpunosti ne zadovoljava osnovne tehničke karakteristike dotičnog bacanja. Bacanje nije izvedeno dovoljno brzo, snažno, niti protivnik ima potrebnu amplitudu leta. Ujedno, bacanje nema dvije ispravne od tri faze bacanja (ili su preslabo izvedene).

Svi podaci su obrađeni postupcima deskriptivne i komparativne statistike. Iz prostora deskriptivne statistike, za svaku varijablu, izračunate su mjere centralne tendencije (aritmetička sredina) i mjera disperzije (standardna devijacija), dok je za testiranje normalnosti distribucije rezultata primijenjen Kolmogorov-Smirnov test. Za utvrđivanje kvalitativne povezanosti između prediktorskih i kriterijumske varijable primijenjena je regresiona analiza. Svi statistički proračuni su rađeni uz upotrebu aplikacionog statističkog programa SPSS (verzija 20.00).

\section{REZULTATI}

Tabela 1 Deskriptivni pokazatelji prediktorskih varijabli i kriterijumske varijable

\begin{tabular}{llccc}
\hline Variables & $\mathrm{N}$ & Mean & Std. Deviation & KS (p) \\
\hline MBAU20 & 67 & 3.43 & 1.76 & .19 \\
\hline MBAU10 & 67 & 11.67 & 10.48 & .27 \\
\hline MBAP20 & 67 & 6.14 & 5.77 & .29 \\
\hline MBAP10 & 67 & 4.05 & 3.17 & .31 \\
\hline MBAU2Z & 67 & 2.53 & 1.32 & .23 \\
\hline MBAU1Z & 67 & 2.97 & 1.03 & .25 \\
\hline MBAP2Z & 67 & 2.37 & .79 & .29 \\
\hline MBAP1Z & 67 & 2.00 & .71 & .20 \\
\hline TBINOT & 67 & 6.82 & 1.02 & .45 \\
\hline
\end{tabular}

Legenda: N - broj ispitanika; Mean - aritmetička sredina; Std. Deviation - standardna devijacija; KS(p) vrijednost vjerovatnoće Kolmogorov-Smirnov test; MBAU20 - stajanje na dvije noge uzdužno na klupici za ravnotežu s otvorenim očima, MBAU10 - stajanje na jednoj nozi uzdužno na klupici za ravnotežu s otvorenim očima, MBAP20 - stajanje na dvije noge poprečno na klupici za ravnotežu s otvorenim očima, MBAP10 - stajanje na jednoj nozi poprečno na klupici za ravnotežu s otvorenim očima, MBAU2Z - stajanje na dvije noge uzdužno na klupici za ravnotežu sa zatvorenim očima, MBAU1Z - stajanje na jednoj nozi uzdužno na klupici za ravnotežu sa zatvorenim očima, MBAP2Z - stajanje na dvije noge poprečno na klupici za ravnotežu sa zatvorenim očima, MBAP1Z - stajanje na jednoj nozi poprečno na klupici za ravnotežu sa zatvorenim očima, TBINOT - tehnika bacanja izbijanjem noge otpozadi.

Paspalj, D., et al.: Značaj ravnoteže...Sportlogia 2017, 13 (1), 18-28. Stranica 23. 
U Tabeli 1 prikazani su rezultati deskriptivne statistike mjera koje su korištene za procjenu motoričke sposobnosti ravnoteže, kao i mjera kojima je procjenjivana efikasnost izvođenja tehnike bacanja izbijanjem stajne noge otpozadi. Rezultati Kolmogorov-Smirnovog testa odgovaraju normalnosti rasporeda dobijenih rezultata. Prosječna ocjena efikasnosti izvođenja tehnike bacanja izbijanjem noge otpozadi iznosi 6,82 .

U tabelama 2 i 3 prikazane su relacije između zavisne varijable bacanje izbijanjem stajne noge otpozadi (TBINOT) i udruženih nezavisnih varijabli za procjenu motoričke sposobnosti ravnoteže.

Tabela 2 Parametri multiple regresije motoričke sposobnosti ravnoteže za varijablu TBINOT

\begin{tabular}{ccccc}
\hline $\mathrm{R}$ & $\mathrm{R}^{2}$ & $\begin{array}{c}\text { Standardna greška } \\
\text { ocjene }\end{array}$ & $\mathrm{F}$ & $\mathrm{p}$ \\
\hline $.351^{\mathrm{a}}$ & .123 & 1.028 & 1.017 & .434 \\
\hline
\end{tabular}

a Prediktori (konstante) MBAU20, MBAU10, MBAP20, MBAP10, MBAU2Z, MBAU1Z, MBAP2Z, MBAP1Z b Zavisna varijabla TBINOT

Tabela 3 Koeficijenti regresije motoričke sposobnosti ravnoteže za varijablu TBINOT

\begin{tabular}{|c|c|c|c|c|c|c|}
\hline & \multirow[t]{2}{*}{ Model } & \multicolumn{2}{|c|}{$\begin{array}{l}\text { Nestandardizovani } \\
\text { koeficijenti }\end{array}$} & \multirow{2}{*}{$\begin{array}{l}\text { Standardizovani } \\
\text { koeficijenti } \\
\text { Beta }\end{array}$} & \multirow[t]{2}{*}{$\mathrm{t}$} & \multirow[t]{2}{*}{$\mathrm{p}$} \\
\hline & & B & $\begin{array}{c}\text { Standardna } \\
\text { greška }\end{array}$ & & & \\
\hline \multirow{9}{*}{1} & (Constant) & 6.344 & .616 & & 10.304 & .000 \\
\hline & MBAU20 & -.070 & .078 & -.120 & -.904 & .370 \\
\hline & MBAU10 & .005 & .013 & .053 & .363 & .718 \\
\hline & MBAP20 & .012 & .026 & .068 & .473 & .638 \\
\hline & MBAP10 & -.110 & .056 & -.340 & -1.961 & .055 \\
\hline & MBAU2Z & .037 & .123 & .047 & .298 & .767 \\
\hline & MBAU1Z & .268 & .154 & .270 & 1.739 & .087 \\
\hline & MBAP2Z & -.110 & .191 & -.085 & -.576 & .567 \\
\hline & MBAP1Z & .205 & .236 & .142 & .869 & .388 \\
\hline
\end{tabular}

a. Zavisna varijabla: TBINOT

B - Beta koeficijent; Std. Error - standardna greška; t - t test; p - statistička značajnost; MBAU20 - stajanje na dvije noge uzdužno na klupici za ravnotežu s otvorenim očima, MBAU10 - stajanje na jednoj nozi uzdužno na klupici za ravnotežu s otvorenim očima, MBAP20 - stajanje na dvije noge poprečno na klupici za ravnotežu s otvorenim očima, MBAP10 - stajanje na jednoj nozi poprečno na klupici za ravnotežu s otvorenim očima, MBAU2Z - stajanje na dvije noge uzdužno na klupici za ravnotežu sa zatvorenim očima, MBAU1Z - stajanje na jednoj nozi uzdužno na klupici za ravnotežu sa zatvorenim očima, MBAP2Z - stajanje na dvije noge poprečno na klupici za ravnotežu sa zatvorenim očima, MBAP1Z - stajanje na jednoj nozi poprečno na klupici za ravnotežu sa zatvorenim očima, TBINOT - tehnika bacanja izbijanjem noge otpozadi.

Paspalj, D., et al.: Značaj ravnoteže...Sportlogia 2017, 13 (1), 18-28. Stranica 24. 
Rezultati regresione analize prikazani u Tabeli 2 pokazuju da ne postoji statistički značajna kvalitativna povezanost između prediktorskih i kriterijumske varijable, što rezultira nemogućnošću predikcije rezultata izvođenja tehnike bacanja izbijanjem noge otpozadi na osnovu motoričke sposobnosti ravnoteže. Koeficijent multiple korelacije ukazuje na malu saglasnost zavisne varijable sa nezavisnim varijablama, dok koeficijent višestruke determinacije objašnjava $12,3 \%$ zajedničkog varijabiliteta sa kriterijumom, pri čemu vrijednosti F-testa i ostvarenog nivoa značajnosti $(\mathrm{p}=0,434)$ ukazuju na odsustvo prediktivnog uticaja na njega. Ostalih $87,7 \%$ u objašnjavanju zajedničkog varijabiliteta može se pripisati nekim drugim antropološkim karakteristikama i sposobnostima koje nisu bile predmet ovog istraživanja.

U Tabeli 3 prikazane su vrijednosti Beta koeficijenata koje daju informacije o pojedinačnom uticaju testova za procjenu motoričke sposobnosti ravnoteže na efikasnost izvođenja tehnike bacanja izbijanjem stajne noge otpozadi. Iz Tabele je vidljivo da nijedna varijabla pojedinačno nema statistički značajnu povezanost sa efikasnošću izvođenja tehnike bacanja izbijanjem noge otpozadi iz programa SFO-a. Na granici statističke značajnosti $(0,055)$ nalazi se varijabla stajanje na jednoj nozi poprečno na klupici za ravnotežu s otvorenim očima (MBAP1O), čiji koeficijent Beta iznosi - 0,34, što znači da ta promjenjiva pojedinačno najviše doprinosi objašnjavanju zavisno promjenljive, kada se oduzme varijansa koju objašnjavaju sve ostale promjenjive u modelu. Malo manji doprinos je ostvarila varijabla stajanje na jednoj nozi uzdužno na klupici za ravnotežu sa zatvorenim očima (MBAU1Z), čiji koeficijent Beta iznosi 0,270, a koja je takođe blizu statističke značajnosti $(0,087)$, dok ostale varijable nisu ostvarile jedinstven doprinos predikciji zavisno promjenjive, što može biti posljedica njihovog međusobnog preklapanja.

\section{DISKUSIJA}

Prosječna ocjena efikasnosti izvođenja tehnike bacanja izbijanjem noge otpozadi iznosi 6,82. Razlog ovakvom dostignuću izvođenja tehnike moguće je potražiti u relativno malom broju časova obuke, zbog čega studenti nisu bili u mogućnosti da izvedu optimalan broj njenog ponavljanja. Raspoloživi broj časova ne samo da im nije obezbijedio usvajanje spoljašnje forme izvođenja tehnike, već i sticanje unutrašnje forme koja podrazumijeva optimalnu dinamiku i kinematiku predviđenu datim kriterijumima njenog izvođenja. Nadalje, ukoliko se u obzir uzme složenost posmatrane tehnike, odnosno njena specifikacija motoričkih i drugih sposobnosti, ovakav rezultat je donekle i očekivan, jer je u pitanju kompleksna tehnika koja zahtijeva visok nivo motoričkih ali i kognitivnih sposobnosti. U prilog ovome ide i istraživanje koje je vršio Rađo (2001), u kome on ravnotežu izdvaja kao dominantnu motoričku sposobnost u izvođenju bacanja izbijanjem noge otpozadi (o soto gari), posebno u fazi stajanja na jednoj nozi i izmahivanja drugom nogom. Dalje, on tvrdi da je pored motoričkih sposobnosti (ravnoteže) kognitivno procesuiranje najviše povezano sa kvalitetom izvođenja pomenute tehnike. Dakle, na osnovu praktičnog iskustva i dosadašnjih istraživanja, moguće je zaključiti da je za efikasno izvođenje pomenute tehnike neophodno koordinisano djelovanje čovjeka kao cjelovitog biološkog sistema (potrebno je dostići nivo automatizma), što s obzirom na raspoloživo vrijeme obučavanja i prethodna iskustva većine ispitanika objektivno nije bilo moguće.

\footnotetext{
Paspalj, D., et al.: Značaj ravnoteže...Sportlogia 2017, 13 (1), 18-28. Stranica 25.
} 
Za rezultate dobijene regresionom analizom objašnjenje se može potražiti u kinematici i dinamici izvođenja posmatrane tehnike bacanja. Naime, tehnika bacanja izbijanjem noge otpozadi izvodi se u skladu sa biomehaničkim principima, maksimalnom brzinom i optimalnim nivoom sile, pri čemu se odnosi segmenata pojedinih dijelova tijela mijenjaju. Promjena položaja dijelova tijela utiče na promjenu ravnotežnog položaja, kojom prilikom se zbog premještanja težišta tijela i smanjenja površine oslonca javljaju pojačani zahtjevi za održavanje ravnoteže, pri čemu izvođač pored održavanja vlastite ravnoteže nakon realizovanog bacanja mora kontrolisati i položaj tijela protivnika prilikom pada na podlogu. Objašnjenje dobijenih rezultata moguće je potražiti i u samoj strukturi izvođenja tehnike bacanja izbijanjem noge otpozadi. Tehnika se, kao što je već poznato, ubraja u složenu strukturu kretanja već samim tim što ga čine različiti, ali tečni pokreti i kretanja spojeni u cjelinu. Zbog same kinematike i dinamike izvođenja tehnike izbijanja noge otpozadi javlja se poremećaj ravnoteže tijela, posebno izražen u drugoj fazi izvođenja gdje se vrše brzi kompenzatorni pokreti tijelom i glavom naprijed, pri čemu se izvođač nalazi na jednoj nozi (smanjena površina oslonca) tako da je njegova težina tijela prebačena na stajnu nogu. U ovoj fazi izvođenja javlja se pojačan zahtjev za održavanje ravnoteže koji se zasniva na sistemu međusobnih dejstava više organa koji su odgovorni za prostornu orijentaciju tijela. Za sve vrijeme izvođenja tehnike koordinacijom i integracijom informacija koje iz mišića, tetiva i zglobova stižu do motorne kore i malog mozga, gotovo trenutno se vrši ispravka ravnoteže sve do njene potpune stabilizacije. Na žalost, u ovom istraživanju, pomoću odabranih testova procjenjivana je statička ravnoteža za koju je u najvećem dijelu odgovoran sistem koji uključuje informacije iz zglobova i vibracionih senzora koji daju informacije o položaju tijela u mirovanju, pa je zato i razumljivo što nije dobijen signifikantan uticaj ravnoteže na izvođenje tehnike bacanja izbijanjem noge otpozadi. Drugi mogući razlog je, prije svega, nedostatak vremena za obuku, tako da je dostignut relativno nizak stepen usvojenosti tehnike koji nije omogućio potpunu povezanost snage i koordinacije pojedinih dijelova tijela kod naših studenata. Slične rezultate dobio je Gužvica (2008) istražujući povezanost ravnoteže sa nivoom izvođenja tehnike udaraca čelom pesnice u karateu, pri čemu je utvrdio da statička i dinamička ravnoteža međusobno uopšte ne koreliraju. Daljim upoređivanjem rezultata ovog istraživanja sa rezultatima drugih istraživanja u kojima je istraživana ravnoteža kao motorička sposobnost (Metikoš, Hofman, Prot, Pintar i Oreb 1989) i njezin značaj u sklopu faktorske strukture uspješnosti u džudou (Sertić 2004; Paillard, Montoya i Dupui, 2007; Bratić, Nurkić i Cicović, 2014) vidimo da su dobijeni skoro identični rezultati.

\section{ZAKLJUČAK}

Na uzorku od 67 ispitanika muškog pola, uzrasne dobi od $19 \pm 0,6$ godina, ispitivan je uticaj motoričke sposobnosti ravnoteže na efikasnost izvođenja tehnike bacanja izbijanjem noge otpozadi. Primijenjena parametrijska statistika je pokazala da se na osnovu testova pomoću kojih je analizirana kao značajan faktor za izvođenje motoričkih programa ravnoteža kao motorička sposobnost nije pokazala značajna za izvođenje tehnike izbijanjem noge otpozadi. Regresionom analizom je takođe utvrđeno da se nije pokazala statistički značajna povezanost primijenjenih testova pojedinačno sa kvalitetom izvođenja navedene tehnike, što ukazuje na to da se u budućim sličnim istraživanjima konstruišu ili odaberu konzistentni, specifični testovi koji bi preciznije objasnili povezanost ravnoteže sa kvalitetom izvođenja tehnike bacanja izbijanja stajne noge. Pretpostavka je da bi specifični testovi mogli biti od pomoći, ne samo u cilju lakšeg i bržeg usvajanja i efikasnijeg obučavanja programskih sadržaja iz SFO-a, već i prilikom selekcije kandidata za upis na Fakultet bezbjednosnih nauka.

Paspalj, D., et al.: Značaj ravnoteže...Sportlogia 2017, 13 (1), 18-28. Stranica 26. 


\section{LITERATURA}

Arlov, D. (2001). Alati samoodbrane. Novi Sad, RS: SIA.

Bratić, M., Nurkić, M., \& Cicović, B. (2014). Judo. Niš, RS: Istočno Sarajevo, BiH: Fakultet sporta i fizičkog vaspitanja, Univerzitet u Nišu i Fakultet fizičkog vaspitanja i sporta, Univerzitet u Istočnom Sarajevu.

Drid, P. (2005). Uticaj specifičnih motoričkih vježbi na efikasnost motornog učenja elementarnih džudo tehnika. Neobjavljena doktorska disertacija, Fakultet fizičke kulture, Univerzitet u Novom Sadu.

Gužvica, M. (2006). Valorizacija novog modela situaciono-motoričke obuke studenata Visoke škole unutrašnjih poslova. Doktorska disertacija. Fakultet sporta i fizičkog vaspitanja, Univerzitet u Beogradu.

Gužvica, M. (2008). Korelacija sposobnosti ravnoteže sa nivoom izvođenja tehnike udaraca čelom pesnice u karateu. Bezbjednost policija građani, (2), 59 -70.

Jarić, S. (1997). Biomehanika humane lokomocije sa biomehanikom sporta. Beograd, RS: Dosije.

PMCid:PMC1184399

Kosinac, Z. (2009). Igra u funkciji poticaja uspravnog stava i ravnoteže u djece razvojne dobi. Život i škola, 22 (55), $11-22$.

Kuleš, B. (2008). Trening judaša. Zagreb, RH: Kugler.

Metikoš, D., Hofman, E., Prot,F., Pintar, Ž., \& Oreb, G. (1989). Mjerenje bazičnih motoričkih dimenzija sportaša. Zagreb, RH: Fakultet za fizičku kulturu.

Milošević, M., (2013). Specijalno fizičko obrazovanje. Naučne osnove. Beograd, RS: CEDIP.

Nićin, Đ. (2000). Antropomotorika. Novi Sad, RS: Fakultet fizičke kulture, Univerzitet u Novom Sadu.

Paillard, T., Montoya, R., \& Dupui, P. (2007). Postural adaptations specific to preferred throwing techniques practiced by competition-lekel judoists. Journal of Electromyography and Kinesiology, 17(2), 241-244.

https://doi.org/10.1016/j.jelekin.2006.01.006

PMid:16563801

Rađo, I. (2001). Judo. Sarajevo, BiH: Fakultet sporta i tjelesnog odgoja. Univerzitet u Sarajevu.

Sekulić, D., \& Metikoš, D. (2007). Osnove transformacijskih postupaka u kineziologiji - Uvod u Osnovne Kineziološke Transformacije. Split, RH: Fakultet prirodoslovno-matematičkih znanosti i kineziologije, Sveučilište u Splitu.

Sertić, H. (2004). Osnove borilačkih sportova. Zagreb, RH: Kineziološki fakultet, Sveučilište u Zagrebu.

Zaciorski, V. M., (1975). Fizička svojstva sportiste. Beograd, RS: NIP Partizan. 


\section{SUMMARY}

The aim of the research is to determine the relation of balance as a motor ability with the performance of the major outer reap throw technique (according to the program of special physical education-SPE), for a possible modification of mentioned training technique and selection of appropriate resources to improve the same. The study was conducted on a sample of 67 male subjects. The sample of variables consisted of eight standard tests for the evaluation of the balance of motor ability, and the variable for assessing the level of adoption of the major outer reap throw technique from the SPE program. Analyzing the results, obtained by regression analysis, it was found that there was no statistically significant correlation between variables for balance assessment and the efficiency of major outer reap throw technique. Since the statistically significant correlation between applied test for the balance evaluation and the observed technique performance was not found, it seems necessary that in similar future studies specific and consistent tests, which more accurately explain the dependence between the balance and the quality of a major outer reap throw technique, should be constructed or selected.

Keywords: Balance, technique of performance, connectivity

Paspalj, D., et al.: Značaj ravnoteže...Sportlogia 2017, 13 (1), 18-28. Stranica 28. 